\title{
Quality Selection, Sectoral Heterogeneity and Chinese Exports
}

\author{
Richard Kneller and Zhihong Yu ${ }^{1}$ \\ University of Nottingham, GEP, CESifo
}

\begin{abstract}
Recent models of international trade have identified product quality as an important determinant of bilateral trade flows. In this paper we examine the relationship between the characteristics of the export market and the aggregate quality of products using Chinese data. We find evidence that product unit values vary with standard gravity variables in a different manner across sectors of the Chinese economy, and run contrary to earlier findings for the U.S. These results are not compatible with existing heterogeneous firm trade models with constant mark-up such as Melitz (2003) model and its extension to include product quality by Baldwin and Harrigan (2011). We construct a heterogeneous firm trade model with quality differences as in Baldwin and Harrigan (2011) and spatial price discrimination based on Melitz and Ottaviano (2008), and show that the model provides plausible explanations for our empirical finds as well as other existing findings in the literature.
\end{abstract}

Key words: product quality, heterogeneous firms, Chinese exports

JEL code: $F 1, F 12$

\footnotetext{
${ }^{1}$ We would like to thank Peter Egger, participants in the GEP conference Malaysia and the ETSG 2008 annual conference for helpful comments. Zhihong Yu would like to thank RCUK for providing financial support for this research project. Richard Kneller would like to thank the Leverhulme Trust (Programme Grant F114/BF) for financial support. For correspondence: richard.kneller@nottingham.ac.uk; zhihong.yu@nottingham.ac.uk
} 


\section{Introduction}

Recent empirical modelling by Schott (2004), Hummels and Skiba (2004), Hummels and Klenow (2005), Hallak (2006) and Baldwin and Harrigan (2011) has shown that the average unit values of internationally traded products vary with the per capita income, factor intensities, distance and market size of trading partners. These empirical regularities have been interpreted as suggesting that differences in product quality are an important determinant of the pattern of international trade flows. Theoretical explanations consistent with this evidence have centred on the 'Alchien-Allen effect', and more recently the 'selection effects' that come from an extension of the heterogeneous firm trade model with CES demand based on Melitz (2003) to allow for differences in product quality by Baldwin and Harrigan (2011) and Johnson (2012).

In this paper, motivated by the empirical evidence that we present of a deviation between the spatial patterns of unit values for Chinese exports at the product level from that predicted by the Melitz (2003) model of trade with product quality differences a la Baldwin and Harrigan (2011) and Johnson(2012), we build a endogenous mark-up model based on Melitz and Ottaviano (2008) with cross-firm quality heterogeneity and cross-sector heterogeneity as in Baldwin and Harrigan(2012). In our new model (f.o.b.) export prices (mark-ups) change with the location (distance) and market size of export destinations via both the 'selection effect' and the 'price discrimination' effect, that occur when export price mark-ups are endogenous. These selection and price discrimination effects work in opposite directions in the product quality model, leaving the relationship of export unit values with market size and distance ambiguous, but reinforce each other in a model where differences in firms' productive efficiency, as in Melitz (2003), are key.

Our empirical evidence relies on data for over 7,000 Chinese products and 168 export destinations for the years 1997 to 2002. Grouping products according to their broad industry characterisation we find marked differences in the relationship between unit values and export market characteristics (distance and market size) across industries. For around two-thirds of the observations (12 industries) the coefficients on both market size and distance are found to be positive, in a quarter of the observations (4 industries) a positive coefficient is found on the distance variable and negative coefficient found for market size, and in 7 per cent of the observations ( 3 industries) both variables have a negative relationship with average unit values.

These results cannot be understood using the model of international trade where firms differ in their productive-efficiency due to Melitz (2003) alone, while the Baldwin-Harrigan (2007) extension of 
Melitz to account for differences in the quality of goods produced by firms can explain the results for less than 10 per cent of the observations found in the data. ${ }^{2}$ A heterogeneous firm model with quality differences and spatial price discrimination is however, consistent with the Chinese evidence. In particular, following Baldwin and Harrigan (2011), we assume firms differ in both marginal costs and quality, with a strictly positive quality-cost elasticity $\sigma$. High marginal costs produce higher quality products and also result in higher prices within the same product category. Due to the existence of positive trade costs, firms self-select into the export market in terms of cost or quality. When $\sigma>1$ (quality competition), quality increases disproportionally more than costs. Thus high-cost-quality firms yield greater profits and become exporters, leaving the low-cost-quality firms to serve only the domestic market.

Under our model with endogenous mark-up as in Melitz and Ottaviano (2008), increasing trade costs or larger market size of the importer lead to a higher quality threshold required to export. Hence, average product quality as well as the unit value of exports increases with distance and market size of the export destination. This is the "selection effect". However, since mark-up is endogenous, each firm charges different prices across destinations, which turn out to be lower in larger and more distant markets. This is the "price discrimination effect", which is exactly the opposite of the selection effect. As a result, the net effect is ambiguous, depending on which effect dominates. On the other hand, when $\sigma<1$ (efficiency competition), the price discrimination effect remains the same, whilst the selection mechanism is reversed: low cost-price-quality firms are selected into the export market, so that increasing distance and smaller market size leads to lower average product quality and f.o.b. price. Hence, the net effect is unambiguous and identical to the Melitz-Ottaviano (2008) model without quality differentiation. Hence, our model provides a plausible explanation for the empirical findings on the unit value of Chinese exports at product-level, which cannot however be fully explained by other models discussed above.

Our paper contributes to the fast growing literature on product quality and international trade, and, in particular, the link between unit value and importers' characteristics. At the product level, both Hummels and Skiba (2004), using 6 digit HS data for the US, and Baldwin and Harrigan (2011), using 10 digit HS data, found that average unit value increases with measures of (per unit) transportation cost/distance. For explanation, Hummels and Skiba (2004) constructed a simple theoretical model to demonstrate that their findings are consistent with the "Alchien-Allen effect", which argues that, in the presence of quality differentiation within products, higher per unit transport cost lowers the relative

\footnotetext{
${ }^{2}$ The predicted relationship for the Baldwin and Harrigan (2007) model holds for just three of the 19 industries we study (and in only one are both distance and market size significant), where these account for just 7.8 per cent of the total observations (6.9 per cent of HS8 codes).
} 
price of high quality goods, and thus increases the relative demand for high quality products. The 'Alchien-Allen effect' is, however, not well suited to explaining the negative impact of importers' market size on average unit values found by Baldwin and Harrigan (2011). To understand the effects of both distance and market size, they incorporate quality differentiation into the Melitz (2003) model where production of high quality products requires higher marginal costs. They show that when the quality-cost elasticity is high (quality competition), average unit value at the product level increases with the importer's distance but decreases with its market size, and they confirmed this prediction in their data.

In a related study, using 2006 Chinese export data Harrigan and Deng (2008) also find that export unit values are increasing in distance from China to export markets. They offer a different theoretical explanation, based on an extension of Eaton and Kortum (2002) model to embed a Washington-apple like effect. Furthermore, both Hummels and Skiba (2004) and Baldwin and Harrigan (2011) find a very robust positive link between the average unit value and the importer's level of income proxied by GDP per capita, which is consistent with the view that unit value reflects quality of products as higher income countries demand higher quality products ${ }^{3}$.

Finally, Manova and Zhang (2009) using very disaggregated firm-product-country level data for China and find variation in unit values across destinations but offer an alternative explanation. In their model more successful exporters use higher-quality inputs to produce higher quality goods and firms vary the quality of their products across destinations. Bastos and Silva (2010), Martin (2012) and Gorg et al. (2010) also use transaction level data and find significant within-firm variation in f.o.b prices across destinations and their links to the characteristics of importer's market, which strongly support "pricing to market" behaviour by firms and which cannot be otherwise explained in trade models with CES demand and constant mark-up as in Melitz (2003) and its extensions incorporating quality differences.

In our model, we show that the combination of price discrimination effect derived from the linear demand as Melitz-Ottaviano (2008), and the "quality/efficiency selection effect" based on a positive relation between quality and marginal cost as in Baldwin-Harrigan (2011), can explain the existing

\footnotetext{
${ }^{3}$ Schott (2008) uses highly disaggregated US import data and shows that the mix of products exported by China to the US displays greater similarity to those of high income countries, but the price paid for these products (the unit value) is substantially lower. Under an assumption that differences in prices reflect differences in quality, Schott (2008) interprets this as consistent with a view that Chinese exports are of lower quality compared to those exported by high income countries.
} 
empirical evidence between product level unit value and the characteristics of the export destinations, and how this pattern could vary across sector . ${ }^{4}$

The rest of this paper is organised as follows. In the next section we describe the data and methodology, while section 3 displays the results. The results show that for most export sectors seem to fall outside the empirical predictions from the original Melitz (2003) model even incorporating quality differences. In section 4 we instead propose a new version of the quality version of the heterogeneous firm trade model based on Melitz and Ottaviano (2008) with spatial price discrimination that is consistent with the new empirical patterns we obtain for China. This may also explain the differences between the results for China and those from other studies for the U.S.

\section{Data and Method}

The data used for the empirical analysis are originally drawn from Customs General Administration of the People Republic of China for the years 1997-2002. These data record all export transactions, detailing information on the number of units traded (as well as the type of unit), the 'free on board' cost, the destination country and the HS8 industry (which we use here to describe products) as well as information on the ownership of the exporting firm (broken into 9 different types), and the type of trade undertaken (ordinary, processing etc. broken into 18 different types).

From the underlying data we aggregate firms' ownership according to whether they are state owned enterprises, are privately owned or have some degree of foreign ownership and split the type of trade according to whether it is ordinary trade, processing trade or other types. ${ }^{5}$ We use only the part of the data that relates to ordinary trade, leaving a discussion of differences in the estimated relationships with those found for processing trade to Kneller and $\mathrm{Yu}$ (2008).

These data are of a similar type to those used by Harrigan and Deng (2008), previously by Swenson (2007), Chen and Swenson (2007) and detailed more fully in Feenstra, Deng, Ma and Yao (2004), but where they have further information on the location (city - these include in some cases city districts)

\footnotetext{
${ }^{4}$ For other heterogenous firm trade models with linear demand and quality differences, see for example Antoniades (2015) and Baller (2015) . Both papers incorporate quality differences into the Melitz and Ottaviano(2008) with endogenous quality choice by firms. One main difference between our model and their model is that we assume quality is increasing with marginal cost, whilst they assume that quality improvement requires fixed investment. Also see Di Comite, Thisse and Vandenbussche (2014) that allows the demand for each variety to be country-specific, and Eckel, Iacovone, Javorcik and Neary (2015).

${ }^{5}$ We drop the residual observations measuring trade of other types following this classification.
} 
from which the exports originate. The total sample size covers 7,724 HS8 industry codes for which we have non-zero unit values for at least one of the observed three years in our data $(1997,2000$ and 2002 ) by country of destination. The total sample size is 437,271 . As might be expected the number of observations rises over time, from 111,360 (1997) to 173,805 (2002). The results are robust to estimation by year or to pooling the data across years.

Before moving on to the regression analysis we briefly detail some of the features of the data. A defining feature of our results is the variation across industries. We report in Table 1 the number of observations available at a broad industry level. As can be seen from the Table, four sectors (Chemicals (HS codes 28-38), Textiles (HS codes 50-63), Base Metals (HS codes 72-83) and Machinery \& Equipment (HS codes 84-85)) account for 52 per cent of all observations. ${ }^{6}$ In Figures 1a and $1 \mathrm{~b}$ we report the distribution of the number of countries exported to within each HS 8 product category for two industrial sectors (Chemicals and Machinery \& Equipment). As can be seen from the figure the distribution is in both cases highly skewed with most products being exported to just a few countries.

There are some differences between the two sectors however, while the modal value of the number of countries is one in both sectors, the median value is 18 in Chemicals and 27 in Machinery and Equipment. As alternative evidence on the skew in the distribution, 35 per cent of products are exported to less than 10 countries in the Chemicals sector whereas in the Machinery and Equipment sector it is 26 per cent.

The variable of interest in the study is the unit value price of exports for each HS8 product from China to each of the 168 countries listed in the sample and for which we have complete data on the control variables. ${ }^{7}$ This variable captures the f.o.b. export price averaged across all firms that export a given product to a given destination in the theoretical model. Unit value of product $p$ to country $j, u_{p j}$, are calculated by dividing the f.o.b. export value, $V_{p j}$, by export quantity, $Q_{p j}$,

$u_{p j}=V_{p j} / Q_{p j}$

\footnotetext{
${ }^{6}$ In Table A1 in the appendix we report the number of observations per country. As might be expected, countries that are large (measured by GDP) and are geographically relatively close to China have a larger number of observations.

${ }^{7}$ As discussed in Schott (2006), unit values are likely to include measurement error as a result of the misclassification of products. For that reason he, as do we, focus on heterogeneity in prices within product ranges. It should also be noted that Schott (2006) ,as well as Bernard et al. (2007) and Baldwin and Harrigan (2011), use HS 10 digit data.
} 
In the more formal analysis we regress these unit values in period t against a measure of distance from China to country $j$, dist $t_{\mathrm{j} t}$, as well as a measure of market size, $\mathrm{GDP}_{\mathrm{jt}}$, wealth per capita, GDPpc $\mathrm{j}_{\mathrm{jt}}$, a Border dummy, BORDER, a set of time dummies, TD, and product fixed effects. The product (HS8 industry) fixed effects control for differences in average unit value across products as well as any differences in units (kilograms, tonnes etc.). ${ }^{8}$ The regression equation is of the form:

$$
\log \left(u_{p j t}\right)=a_{p}+\beta_{1} \log \left(\text { dist }_{j}\right)+\beta_{2} \log \left(G D P_{j t}\right)+\beta_{3} \log \left(G D P p c_{j t}\right)+\beta_{4} B O R D E R_{j}+\beta_{5} T D+\varepsilon_{p j t}
$$

Data on GDP and GDP per capita are from the World Bank, while the data on distance is a measure of weighted distance taken from CEPii and used previously by Head and Mayer (2002). The average distance from China is 7,795 kilometres. The closest country is recorded as South Korea $(1,123 \mathrm{~km})$ and the furthest is Argentina $(19,110 \mathrm{~km})$.

Using this data we are also able to replicate the type of evidence on unit values presented in Schott (2006) with the Chinese data. In Figures $2 \mathrm{a}$ and $2 \mathrm{~b}$ we consider a scatter plot of unit values against GDP per capita for two HS8 products, Absorbent gauze or muslin bandages (HS8:30059010) and Motorcycles with reciprocating internal combustion piston engine, 50-250cc (87112000). These codes are chosen on the basis that these are products are exported to many countries (135 and 131 countries respectively). Consistent with the evidence for the US, there would appear in both of these graphs a generally positive relationship between average unit values per destination and GDP per capita. For example, the price per kilogram paid for absorbent gauze or muslin bandages is $\$ 0.51$ in Brazil and $\$ 3.33$ in the US and as high as $\$ 9.38$ in Austria. Similarly, there are large differences in the unit price per motorcycle. The unit price is $\$ 170$ in Vietnam, \$417 in Malaysia, \$639 in the US and \$1,995 in New Zealand.

\section{Empirical Results}

In Table 2 we report the results from the regression for unit-prices by broad industrial sector, where we group the results according to the combination of signs on the distance and market size variables. ${ }^{9}$

\footnotetext{
${ }^{8}$ The data have been checked so that the units of measurement are the same within every hs 8 category.
}

\footnotetext{
${ }^{9}$ The regressions include other standard gravity variables such as GDP per capita . For expositional purposes we do not report them in table 4. Consistent with previous studies, the coefficients for GDP per capita are positive for most of the regressions. Details of these results are available from the authors upon request. Also see Kneller and $\mathrm{Yu}(2008)$.
} 
Firstly, in no industries do we find the negative-positive (distance/market size) combination predicted by the 'efficiency sorting' version of the Melitz-Baldwin-Harrigan model where the quality-cost elasticity is less than one. This somewhat surprising as this follows from the original Melitz model and would perhaps represent the standard view of Chinese comparative advantage. Secondly, the positivenegative combination suggested by the 'quality sorting' version of Melitz-Baldwin-Harrigan and the empirical evidence for the US are replicated in Chinese exports for only one industry (Pearls, precious metals and jewellery) out of 19 industries, although there are another three sectors with the expected combination of signs and at least one insignificant coefficient. These four sectors only account to 7.8 per cent of the total observations (6.9 per cent of HS8 codes), while the jewellery sector accounts for 0.3 per cent of observations ( 2.3 per cent of HS8 codes).

The most common combination is for the estimated coefficients on both distance and market size to be positive. For twelve of out 19 industries we find this combination of coefficients and both coefficients are significant in 9 industries, including some crucial export sectors for China such as textiles, wood products, base metals and chemicals. The products with this positive relationship with distance and market size represent 64.7 per cent of the total number of observations, or 67.4 per cent of available product codes. There is also evidence from the previous literature that these results are not unique to Chinese exports. Interestingly this result matches those found for Belgian and French exports in Mayer and Ottoviano (2007). Finally, there are three industries for which we find that average unit values decline with distance and market size. These industries account for a nontrivial proportion of the sample: 27.5 per cent of all observations and 25.7 per cent of products. Both of these two combinations fall outside the predictions of Table 2. Specifically, the positive-positive combination of coefficients estimates, which is found in the majority of Chinese export sectors, is inconsistent with all the existing versions of the heterogeneous firm trade models including the Melitz (2003), Baldwin and Harrigan (2011) and Melitz and Ottaviano (2008). ${ }^{10}$

\section{A Model with Quality sorting and Spatial Price Discrimination}

The Baldwin and Harrigan (2011) paper demonstrates that the sign of the coefficients on distance and market size will be positive and negative respectively, under quality sorting when the elasticity of quality is greater than one, but reversed under efficiency sorting when the quality elasticity is less than one. Our results for China suggest that neither version of these models may apply universally. Specifically, we find variation across industries, and for the majority of industries a combination of signs that do not provide strong support for either version of the model.

\footnotetext{
${ }^{10}$ Baldwin and Harrigan (2011) demonstrate a negative-negative sign combination can be derived from the original Melitz and Ottaviano (2008) model.
} 
In the rest of this section we consider the possibility of an additional mechanism through which spatial variation in unit values might be generated. Specifically, we modify the Melitz-Ottaviano (2007) model by allowing asymmetric varieties and a positive link between the cost and the qualities of varieties as introduced by Baldwin and Harrigan (2007) and Johnson (2007). One important feature of this model is that, unlike the CES case where an exporter will charge identical f.o.b. prices across markets, the optimal firm level f.o.b. export price will vary across export destinations with different distances and market size. We label this effect 'spatial price discrimination'.

With spatial price discrimination, distance and market size affects average export unit value because of the compositional changes of firms entering the export markets, but in addition because of their effect on the f.o.b. price mark-ups for individual firms. We show that by adding these new dimensions, the heterogeneous firm trade model yields combinations of the coefficients for distance and market size in a regression of average unit-values that might explain our Chinese evidence, but also leads to different implications for the pattern of quality sorting and the effects of distance and market size on export quality relative to Baldwin and Harrigan (2011).

\section{The Model}

We begin by considering a closed economy and then extend to the open economy version. Consider an economy with $L$ identical consumers, each supplying one unit of labour as the only factor of production. We follow Melitz and Ottaviano (2008) and assume that preferences across differentiated varieties within a sector are characterised by a quasi-linear utility with a quadratic sub-utility. We modify the demand system to accommodate asymmetric varieties as follows:

$$
u=q_{0}+\alpha \int_{i \in \Omega}\left(z_{i} q_{i}\right) d i-\frac{\gamma}{2} \int_{i \in \Omega}\left(z_{i} q_{i}\right)^{2} d i-\frac{\eta}{2}\left(\int_{i \in \Omega}\left(z_{i} q_{i}\right) d i\right)^{2}
$$

Where $u$ is the utility of an individual representative consumer, $q_{0}, z_{i}, q_{i}$ and $M$ are respectively, consumption by the representative consumer of the homogeneous good, quality of variety $i$ and quantity of variety $i$ in the differentiated sector and the number of varieties available in that sector. We assume that $z_{i} \geq 1$, and it indexes the quality of a variety and consumers enjoy greater utility from a variety with higher value of $z_{i}$. When $z_{i}=1$ for any $i$, the model is identical to the Melitz-Ottaviano (2008) model without quality differences. Parameter $\gamma$ indexes the degree of product differentiation across varieties, and the larger $\gamma$ the more differentiated are varieties. Parameters $\alpha$ and $\eta$ index the degree of substitution between the numeraire good and differentiated goods: the consumer's demand is 
biased toward the differentiated good relative to the numeraire good the higher is $\alpha$ or the lower is $\eta$. $\alpha, \eta$ and $\gamma$ are assumed positive and identical across countries. These preferences lead to the following inverse demand function:

[1] $\frac{p_{i}}{z_{i}}=\alpha-\gamma \cdot z_{i} q_{i}-\eta Q$

Where $Q=\int_{i \in \Omega}\left(z_{i} q_{i}\right) d i$ is the aggregate (quality adjusted) consumption. Let $\Omega^{*} \subset \Omega$ be the subset of varieties consumed $\left(q_{i}>0\right)$. The linear demand system for each individual variety is:

[2] $\quad q_{i}=\frac{L}{z_{i} \gamma}\left(\hat{P}-\frac{p_{i}}{z_{i}}\right), \quad i \in \Omega *$

where $\hat{P} \equiv \frac{\eta M \bar{P}+\alpha \gamma}{\eta M+\gamma}$ is the quality adjusted price-ceiling common for all varieties, above which the demand for an individual variety will be zero. $\bar{P}=\int_{i \in \Omega^{*}}\left(\frac{p_{i}}{z_{i}}\right) d i / M$ represents the average quality-adjusted price of the differentiated varieties, where $M$ is the number of varieties being consumed.

On the production side of the model, labor is the only factor of production. Production of the numeraire good exhibits constant return to scale at unit cost under competitive market. This assumption leads to unit wage. There is a continuum of firms paying a sunk fixed entry cost $f_{e}$ to enter the market, and then randomly draw their constant marginal cost $c_{i}$ from an exogenous common distribution $G(c)$ with support $\left[0, c_{M}\right]$. Since firms' operating profits are $\pi_{i}=\left(p_{i}-c_{i}\right) q_{i}$, the first order condition of profit maximisation yields the following optimal quantity:

$$
q_{i}=\frac{L}{\gamma} \frac{\left[p_{i}-c_{i}\right]}{z_{i}^{2}}
$$

Substituting [3] into [2] we derive the optimal pricing rule given cost $c$ (we omit the firm subscript $i$ hereafter):
[4a] $\quad p(c, z)=(z \cdot \hat{P}+c) / 2$
[4b] $\frac{p(c, z)}{z}=\left(\hat{P}+\frac{c}{\mathrm{z}}\right) / 2$

This yields the optimal quantity of production, revenue and profit. 


$$
q(z, c)=\frac{L}{2 \gamma \cdot z}\left(\hat{P}-\frac{c}{z}\right), \quad \frac{c}{z}<\hat{P}
$$

[6] $\quad r(z, c)=\frac{L}{4 \gamma}\left[\hat{P}^{2}-\left(\frac{c}{z}\right)^{2}\right]$,

$$
\frac{c}{z}<\hat{P}
$$

[7] $\pi(z, c)=\frac{L}{\gamma}\left(\frac{p-c}{z}\right)^{2}=\frac{L}{4 \gamma}\left(\hat{P}-\frac{c}{z}\right)^{2}, \quad \frac{c}{z}<\hat{P}$

where $\frac{c}{z}<\hat{P}$ is the 'survival condition'. Only varieties with quality adjusted costs lower than the price ceiling will face positive demand $(q(z, c)>0)$. Firms producing higher quality products for a given cost will charge higher prices and earn greater revenue and profits, although it does not necessarily follow there will also enjoy higher demand ${ }^{11}$. Note that $[4 b]$ implies a negative relation between the quality adjusted price $(\mathrm{p} / \mathrm{z})$ and quality $(\mathrm{z})$, holding marginal cost $(c)$ constant.

Following Baldwin and Harrigan (2011) and Johnson (2012), we assume that $z$ is positively correlated to $c$. Higher cost firms produce higher quality, $z=c^{\sigma}, \sigma \in[0, \infty)$. Hence, equation [4]-[7] can be rewritten as

$$
\begin{array}{lll}
\text { [8] } & p(c)=\left(c^{\sigma} \cdot \hat{P}+c\right) / 2, & c^{1-\sigma}<\hat{P} \\
\text { [9] } & q(c)=\frac{L}{2 \gamma \cdot c^{\sigma}}\left(\hat{P}-c^{1-\sigma}\right), & c^{1-\sigma}<\hat{P}
\end{array}
$$

$$
r(c)=\frac{L}{4 \gamma}\left[\hat{P}^{2}-c^{2(1-\sigma)}\right], \quad \quad c^{1-\sigma}<\hat{P}
$$

$$
\pi(c)=\frac{L}{4 \gamma}\left(\hat{P}-c^{1-\sigma}\right)^{2}, \quad \quad c^{1-\sigma}<\hat{P}
$$

where $c^{1-\sigma}<\hat{P}$ is the 'survival condition' that must be satisfied in all the above equations to yield positive demand for each variety. From [10] and [11] it is straightforward to show that profit and

${ }^{11}$ From [5], $\frac{\partial q}{\partial z}=\frac{L}{2 \gamma z^{2}}\left(-\hat{P}+\frac{2 c}{z}\right)$, implying an inverse $\mathrm{U}$ shape relation between demand and quality: $q(c, z)$ is maximised when $z=2 c / \hat{P}$. 
revenue are increasing (decreasing) in marginal cost when the quality elasticity is greater (less) than one:

$$
\begin{aligned}
& r^{\prime}(c)>0, \quad \pi^{\prime}(c)>0, \quad \forall c>c_{D} \equiv \hat{P}^{\frac{1}{1-\sigma}}, \text { if } \quad \sigma>1 \\
& r^{\prime}(c)<0, \quad \pi^{\prime}(c)<0, \quad \forall c<c_{D} \equiv \hat{P}^{\frac{1}{1-\sigma}}, \quad \text { if } \quad \sigma<1
\end{aligned}
$$

Where $c_{D}$ is the cost cut-off under (above) which firms can survive and earn positive profits when the quality elasticity is low (high). We close the model by assuming free entry into the market. The equilibrium is therefore characterised by the zero net expected profit condition:

$$
\Pi \equiv \int_{c_{D}}^{c_{M}} \pi(c) d G(c)+\int_{0}^{c_{D}} O d G(c)=\frac{L}{4 \gamma} \int_{\hat{P}^{1-\sigma}}^{c_{M}}\left[\hat{P}-c^{1-\sigma}\right]^{2} d G(c)=f_{e} \quad, \quad \text { if } \quad \sigma>1
$$

$$
\Pi \equiv \int_{0}^{c_{D}} \pi(c) d G(c)+\int_{0}^{c_{D}} O d G(c)=\frac{L}{4 \gamma} \int_{0}^{\frac{1}{P^{1-\sigma}}}\left[\hat{P}-c^{1-\sigma}\right]^{2} d G(c)=f_{e}, \quad \text { if } \sigma<1
$$

It is straightforward to show that $\frac{\partial \Pi}{\partial \hat{P}}>0$ and $\frac{\partial \Pi}{\partial L}>0$ for any $\sigma$, so we obtain $\partial \hat{P} / \partial L<0$. In words, larger markets have lower price ceilings in equilibrium. Note that this result is identical to the original Melitz and Ottaviano (2007) model in the absence of quality differences, where they show that larger markets lead to a lower price ceiling and price mark-up. The difference, however, is that here the effect of market size on the survival cost cut off $\left(c_{D} \equiv \hat{P}^{\frac{1}{1-\sigma}}\right.$ ) is ambiguous, depending on the quality elasticity, $\frac{\partial c_{D}}{\partial L}>(<) 0, \sigma>(<) 1 .{ }^{12}$ Larger market leads to increased cost cut-offs, if and only if, the elasticity of quality to cost is greater than one. However, independent of the value of $\sigma$, larger market size always leads to stronger selection into the industry i.e. lower survival rate ${ }^{13}$.

\section{Spatial price discrimination and export selection}

${ }^{12}$ Note that $\frac{\partial c_{D}}{\partial L}=\hat{P}^{\frac{\sigma}{1-\sigma}}\left(\frac{1}{1-\sigma}\right) \frac{\partial \hat{P}}{\partial L}$. Since $\frac{\partial \hat{P}}{\partial L}<0$, the sign of $\frac{\partial c_{D}}{\partial L}$ depends on $\sigma$.

\footnotetext{
${ }^{13}$ Note that firms survive for $c>(<) c_{D}$ when $\sigma>(<) 1$. This indicates that when $\sigma>1$ firm survival rate $1-G\left(c_{D}\right)$ is decreasing in $c_{D}$; and when $\sigma<1$ firm survival rate $G\left(c_{D}\right)$ is increasing in $c_{D}$.
} 
Now we turn to the open economy version of the model to investigate the joint effects of distance and market size on the average unit value of Chinese exports. Consider a world comprising of a home country China, and $J$ foreign countries indexed by $j$. All countries share a common technology, characterised by the distribution of firm level marginal costs $G(c)$ and other parameters, but differ in their market sizes and distance to China. Transportation cost takes the form of a standard melting-iceberg cost $t^{j}>1$ that is increasing in distance.

A firm with cost $c$ from China may decide to serve market $j$ by producing output $q_{X}^{j}(c)$ at a delivered (c.i.f.) price $p_{x}^{j}(c)$. A potential Chinese exporters profit from serving a given foreign market is $\pi_{X}^{j}(c)=\left\lfloor p_{X}^{j}(c)-t^{j} c\right\rfloor q_{X}^{j}(c)$. Analogous to the case in the closed economy in [2]-[9], export demand is $q_{X}^{j}=\frac{L^{j}}{c^{\sigma} \gamma}\left(\hat{P}^{j}-\frac{p_{X}^{j}}{c^{\sigma}}\right)$ and the profit maximising export output must satisfy $q_{X}^{j}=\frac{L^{j}}{\gamma} \frac{\left\lfloor p_{X}^{j}-t^{j} c\right\rfloor}{c^{2 \sigma}}$, which yields the following optimal export price and output:

[14a] $\quad p_{X}^{j}=\frac{1}{2}\left(\hat{P}^{j} c^{\sigma}+c \cdot t^{j}\right), \quad p_{X f}^{j}=\frac{p_{X}{ }^{j}}{t^{j}}=\frac{1}{2}\left(\frac{\hat{P}^{j} c^{\sigma}}{t^{j}}+c\right)$

$$
q_{X}^{j}=\frac{L_{j}}{\gamma z}\left(\hat{P}_{j}-\frac{p_{X}^{j}}{z}\right)=\frac{L^{j}}{2 \gamma \cdot c^{\sigma}}\left(\hat{P}^{j}-c^{1-\sigma} t^{j}\right)
$$

Where $p_{X f}^{j}$ denotes the corresponding optimal f.o.b. price. Most importantly [14a] reveals the existence of 'spatial price discrimination'. Unlike the CES case, where an exporter charges identical f.o.b. prices and mark-ups across markets, now both f.o.b. price $p_{X f}^{j}(c)$ and its mark-up $\left(p_{X f}{ }^{j} / c\right)$ vary with $t^{j}$. Firms charge different f.o.b. prices and mark-ups across export destinations depending on their distance from China. Other things equal, a firm will charge a lower f.o.b price for a more distant market, despite the higher c.i.f. price. The intuition behind this result is that under the subquadratic utility assumption the elasticity of demand varies along a firm's residual demand curve, and the elasticity is greater for higher trade costs. ${ }^{14}$

\footnotetext{
${ }^{14}$ This is because consumer demand is more "sensitive" to changes in price when the c.i.f. price is higher, the later is increasing in trade costs.
} 
In addition, ${p_{X f}}^{j}$ also depends on the "competitiveness of the market" reflected in $\hat{P}^{j}$. Intuitively, when competition in the market is "tougher", the price ceiling $\hat{P}^{j}$ becomes lower, which forces exporters to charge lower f.o.b. prices. Reasoning analogous to the case in the closed economy, and unlike the original Melitz model under CES preferences, market size affects the f.o.b. prices of individual exporters via their effects on $\hat{P}^{j}$. Since $\hat{P}^{j}$ decreases in $L^{j}$ and larger markets lead to tougher competition and lower industrial price ceilings, $p_{X f}^{j}(c)$ decreases in $L^{j}$, exporters charges lower f.o.b. prices in larger markets, other things equal. The intuition is that when selling to a larger market with tougher competition, a firm's residual demand curve shifts inwards leading to a higher price elasticity and thus a lower optimal price.

Finally, [14b] implies that the survival condition written in terms of generating a positive demand in market $j\left(q_{X}^{j}>0\right)$ is :

$$
c^{1-\sigma}<\hat{P}^{j}\left(t^{j}\right)^{-1}
$$

This implies that there exists the following export cost cut off that separates exporters and nonexporters:

$$
c_{X}^{j}=\left(t^{j}\right)^{\frac{1}{\sigma-1}} \hat{P}_{j}^{\frac{1}{1-\sigma}}
$$

For firms satisfying condition [15] , their (positive) export profits will be given by,

$$
\pi_{X}^{j}(c)=\frac{L^{j}}{2 \gamma}\left(\hat{P}^{j}-c^{1-\sigma} t^{j}\right)^{2}
$$

This implies $\pi_{X}^{j}{ }^{\prime}(c)>0$ for $c>c_{X}$ when $\sigma>1$, and $\pi_{X}^{j}{ }^{\prime}(c)<0$ for $c<c_{X}$ when $\sigma<1$. In words, when the quality elasticity is high export profits increase in cost and quality, firms with costs above the export cost cut off earn positive export profits. High quality high price (cost) firms self-select into the export market and we have the pattern of 'quality sorting' by exporters. The opposite holds for low values of the quality elasticity parameter. Then firms will be sorted in terms of having lower cost into the export market and we have the pattern of 'efficiency sorting'. Next we generate the predictions of the effects of market size and distance on average unit value of exports from our model corresponding to the above two sorting patterns, and reveal how they differ from the existing heterogeneous firm trade models. 


\section{Quality Sorting}

Firstly we look at the case of quality sorting. When $\sigma>1$, the cost range of exporters to market $j$ is $\left\lfloor c_{X}^{j}, c_{M}\right\rfloor$, thus the average f.o.b. export price to market $j$ from China is:

$$
\bar{p}_{X f}^{j}=\frac{\int_{c_{X}^{j}}^{c_{M}} p_{X f}^{j}(c) d G(c)}{1-G\left(c_{X}^{j}\right)}=\frac{\int_{c_{X}^{j}}^{c_{M}}\left(c^{\sigma} \hat{P}^{j} t^{j-1}+c\right) d G(c)}{2\left[1-G\left(c_{X}^{j}\right)\right]}
$$

How does $\bar{p}_{X f}^{j}$ responds to distance $\left(t^{j}\right)$ and market size $\left(L^{j}\right) ? \quad t^{j}$ and $L^{j}$ affect $\bar{p}_{X f}^{j}$ via two mechanisms. The first is the 'selection effect'. Variations in $t^{j}$ and $L^{j}$ lead to changes in the export cost cut off $c_{X}^{j}$ and therefore the compositional changes in Chinese exporters to market $j$. As a result, average unit value of Chinese exporters in $j$ will also change. It can be shown from (18) that $\partial \bar{p}_{X f}^{j} / \partial c_{X}^{j}>0$. Further, since as per (16) $\partial c_{X}^{j} / \partial t^{j}>0, \partial c_{X}^{j} / \partial \hat{P}^{j}<0$ when $\sigma>1$, and recall that $\partial \hat{P}^{j} / \partial L^{j}<0$, we conclude that both market size $\left(L^{j}\right)$ and distance $\left(t^{j}\right)$ tend to have positive effects on average export unit value $\left(\bar{p}_{X f}^{j}\right)$ via the selection effect. The intuition behind this result is that, when the quality elasticity is greater than one, firms are sorted into the export market in terms of high quality high cost, with $c_{X}^{j}$ being the minimum marginal cost level required for exporting. A larger market size results in tougher competition and lower price mark-ups in the export market such that selection into the export market is stronger. As a result, more low-cost low-quality firms are forced to leave the export market, which increases the average cost and quality of remaining exporters. Average f.o.b. export price and export quality therefore increases. Reasoning analogously, higher transport costs increase trade barriers, leading to stronger selection and to increased average f.o.b. export price and quality.

However, a second mechanism, namely the 'price discrimination effect', is also at work. As discussed before as per [14a], $p_{x f}{ }^{j}(c)$ decreases in both $t^{j}$ and $L^{j}$ as the optimal f.o.b. export price is now endogenous to the characteristics of the export markets. Hence, the 'selection effects' and 'price discrimination effects' pull in opposite directions, leaving the net effect ambiguous.

\section{Efficiency sorting}

Next we consider the case when the quality elasticity is lower than one. In this version exporters are sorted by having lower costs, therefore the average f.o.b. export price is 
[19] $\bar{p}_{X f}^{j}=\frac{\int_{0}^{c_{X}^{j}} p_{X f}^{j} d G(c)}{G\left(c_{X}^{j}\right)}=\frac{\int_{0}^{c_{X}^{j}}\left(c^{\sigma} P^{j} t^{j-1}+c\right) d G(c)}{2 G\left(c_{X}^{j}\right)}$

Again we can decompose the effects of distance and market size into the selection effect and the price discrimination effect. From [16] $\partial c_{X}^{j} / \partial t^{j}<0$ and $\partial c_{X}^{j} / \partial \hat{P}^{j}>0$ when $\sigma<1$, and from [19] $\bar{p}_{X f}^{j}$ is increasing in $c_{X}^{j}$, therefore $\bar{p}_{X f}^{j}$ decreases in $t^{j}$ and $L^{j}$ (again, using the result that $\left.\partial \hat{P}^{j} / \partial L^{j}<0\right)$. Hence the selection effect is negative for both market size and distance. Furthermore, since the price discrimination effects are also negative, the total effects of both market size and distance on average export quality and unit value are unambiguously negative.

We summarise the above results in Table 3 . Note that Table 3 provides very different predictions compared to those from Baldwin-Harrigan (2011). Our model predicts that under the quality sorting all four possible combinations are possible, depending on whether the selection or price discrimination effect dominates. In contrast, under efficiency sorting both signs are always negative.

\section{Reassessing the evidence from the new model}

As a final exercise we return to the empirical evidence presented in Section 3. As can be seen from the first row of Table 4, using the model with selection and price discrimination the 'double positive' coefficients on distance and market size found for the majority of the Chinese exports and for France and Belgium exports by Mayer and Ottaviano (2008) requires that the quality selection dominates, and that average export quality increases in both distance and market size. Most importantly, and in contrast to the product quality model of Baldwin-Harrigan (2011), which is incompatible with the positive coefficient on distance that we find, the extension of Melitz and Ottaviano (2008) to account for product quality predicts that increasing market size could actually lead to a stronger quality selection effect and therefore higher unit values. The positive coefficient on market size in this model is therefore consistent with a positive coefficient on distance, but also categorically indicates that products are sorted according to their quality by exporters.

As shown in the second to third rows of the table, by incorporating spatial price discrimination it is possible to generate a unified model that can account for other combinations of the coefficient signs in a unit value regression. According this model the positive-negative market size-distance combination found to be significant for the US by Baldwin and Harrigan (2011) would, as in their model, be consistent with an interpretation that product quality characteristics are important in determining 
patterns of trade, but because the (negative) price discrimination effects dominate. Finally, the double negative combination on distance and market size found for two Chinese export sectors, including one of the largest export sectors (Machinery and Equipment), is consistent with both efficiency sorting and quality sorting hypotheses as a consequence of price discrimination in our model. This can be viewed as consistent with Melitz and Ottaviano (2007), but should not necessarily imply efficiency sorting. It is possible that Chinese exporters in the Machinery and Equipment sector are also sorted by quality, but that price discrimination effect dominates the selection effect. Given the importance of the Machinery and Equipment sector to Chinese trade and inward investment flows discriminating between these two hypothesis may be an interesting future exercise. Finally, perhaps somewhat surprisingly, the predictions for unit values from the model of Melitz (2003) are difficult to match with our evidence for Chinese exports. This again stresses the importance of quality differences as a key dimension in our understanding of the relation between export unit value and characteristics of the destination markets.

\section{Concluding Remarks}

In this paper we find new features of the average unit value of Chinese exports compared to existing evidence that could not be fully captured by existing models of heterogeneous firms and international trade. In particular, for the majority of Chinese exports we find unit values increase with both distance and market size, while other combinations of signs are also found to be significant in a few sectors. These findings are difficult to interpret using the Melitz (2003) and its extension by Baldwin Harrigan (2008) to incorporate product quality differences across firms.

To reconcile the gap between our new evidence and the existing theory, we propose an extension of the Melitz and Ottaviano (2008) model allowing for quality differences suggested by Baldwin and Harrigan (2011). A distinguishing feature of this new model is that distance and market size affect unit value through both price discrimination and quality selection effects. Further, in contrast to the common perception that Chinese exports compete internationally through low production costs, our findings imply that in the majority of manufacturing sectors Chinese firms are sorted by the quality of the goods they offer into export markets. 
Figure 1a Distribution of the Number of Export Destinations: Chemical Sector

Number of products

Chemicals

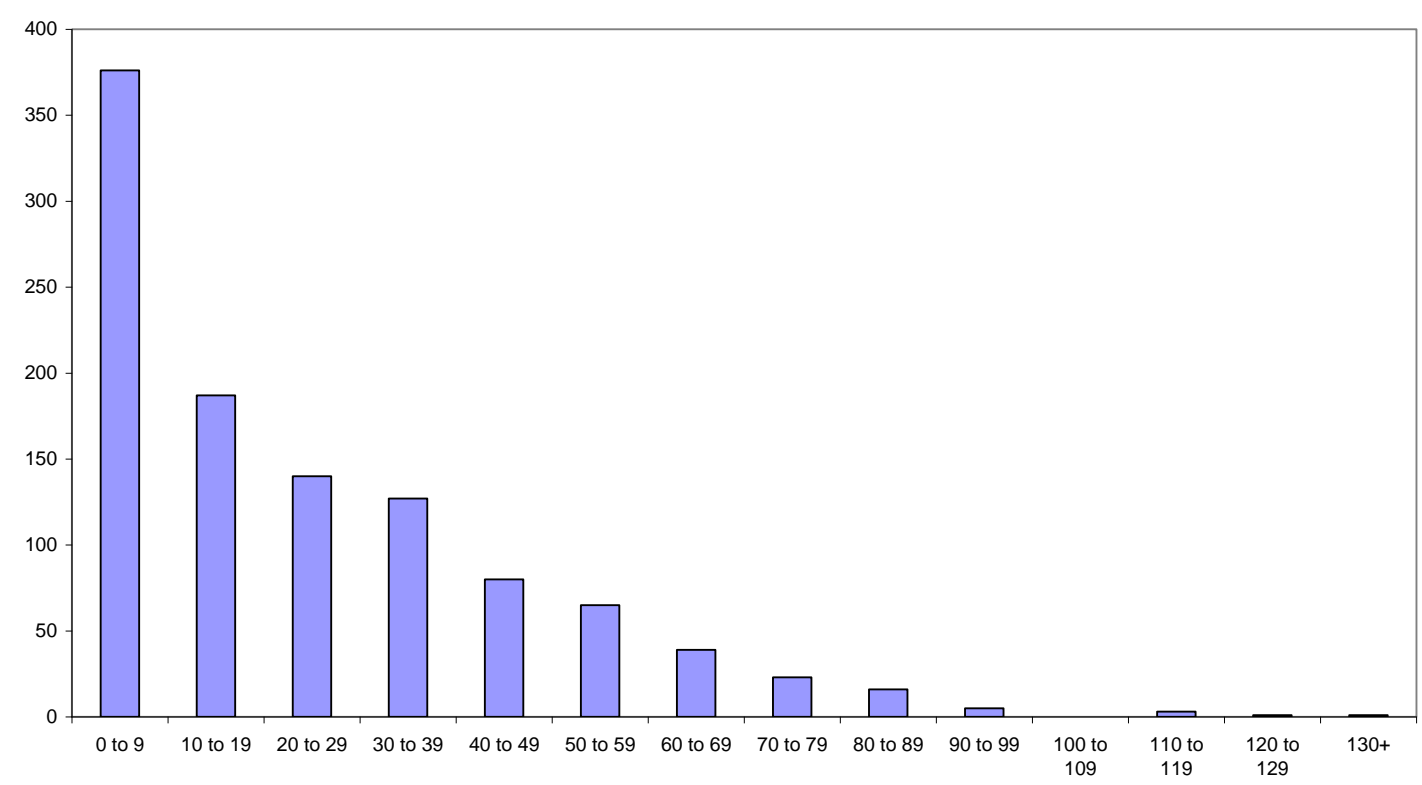

Number of export destinations

Figure 1b Distribution of the Number of Export Destination Countries: Machinery and Equipment Sector

Number of products

Machinery \& Equipment

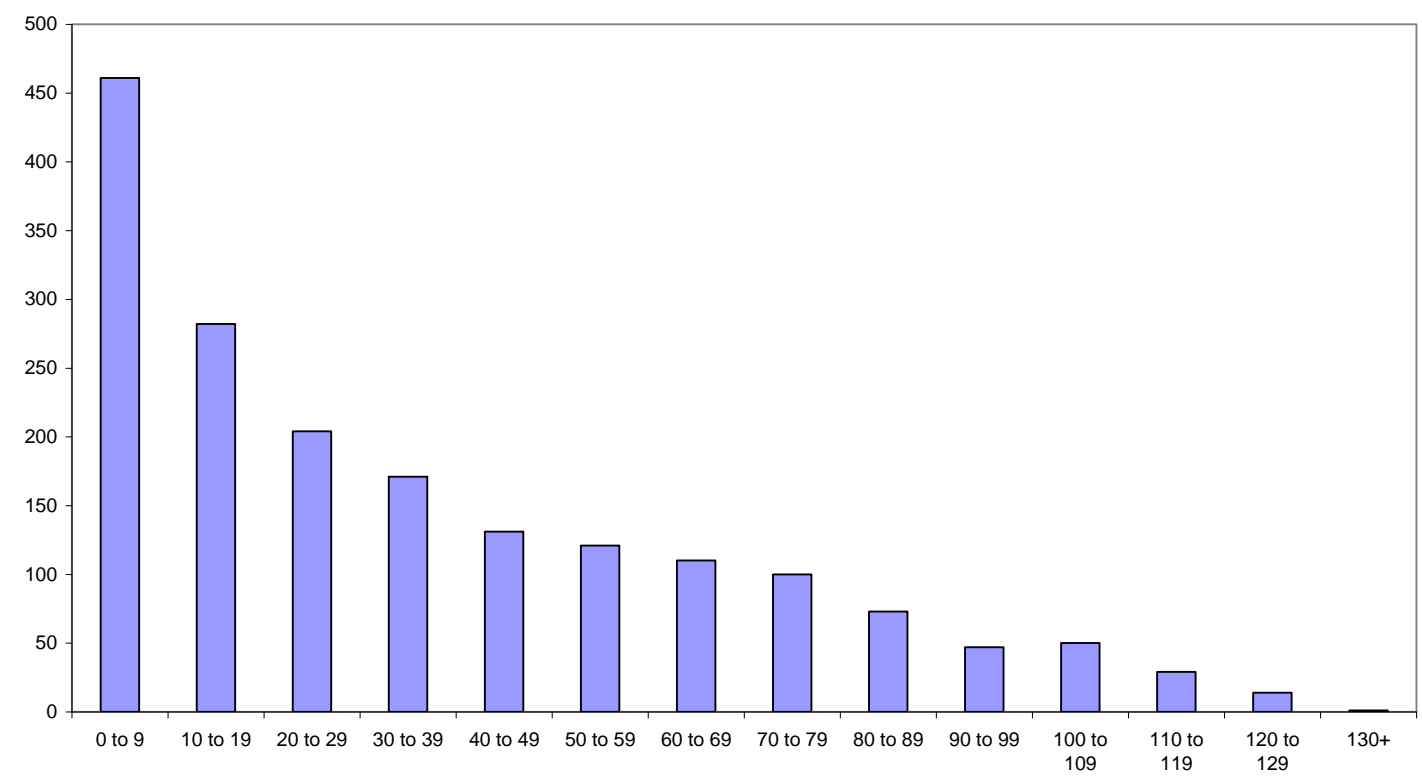

Number of export destinations 
Figure 2a Unit value and GDP per capita for Absorbent gauze or muslin bandages (30059010)

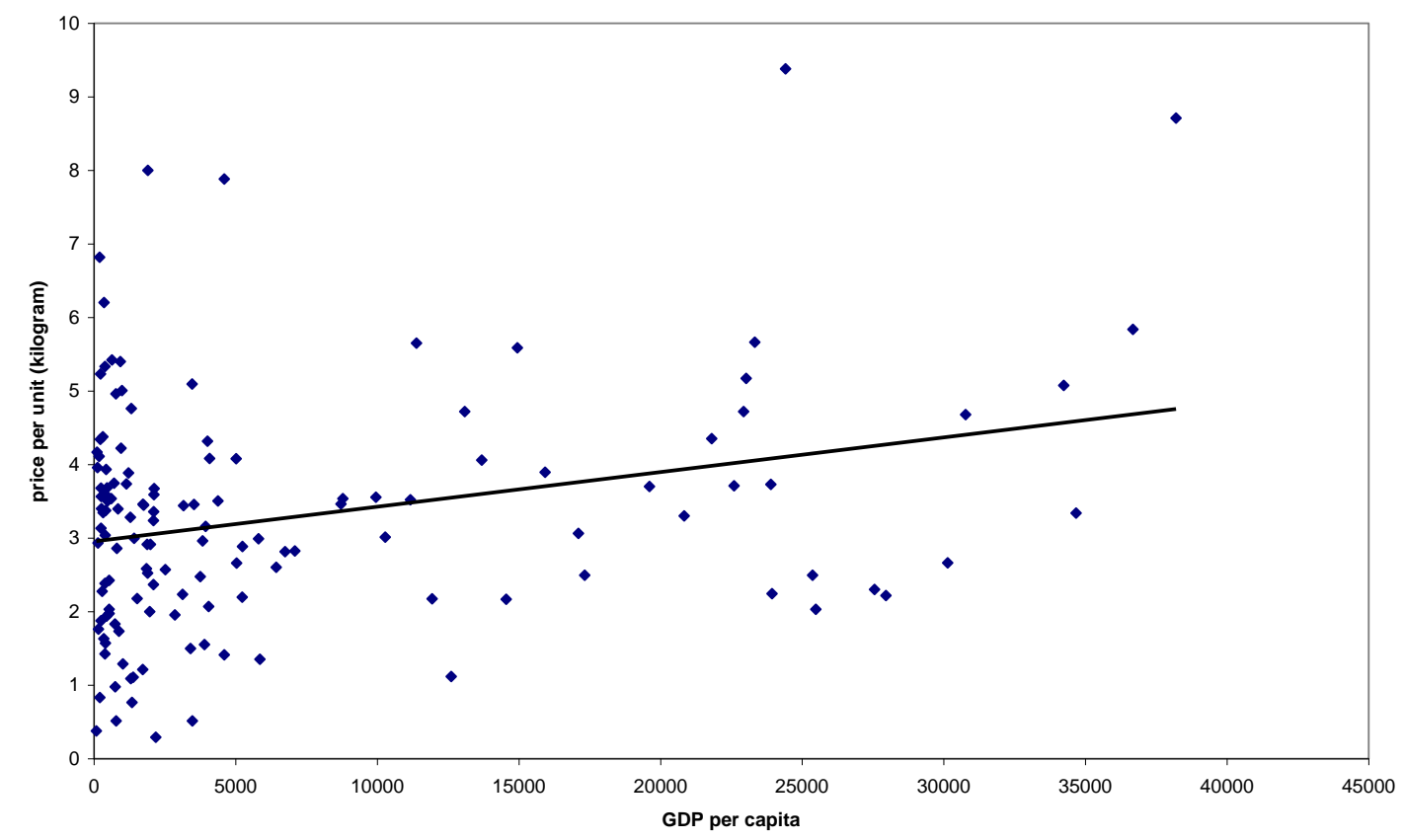

Figure 2b Unit value and GDP per capita for Motorcycles with reciprocating internal combustion piston engine, 50-250cc (87112000)

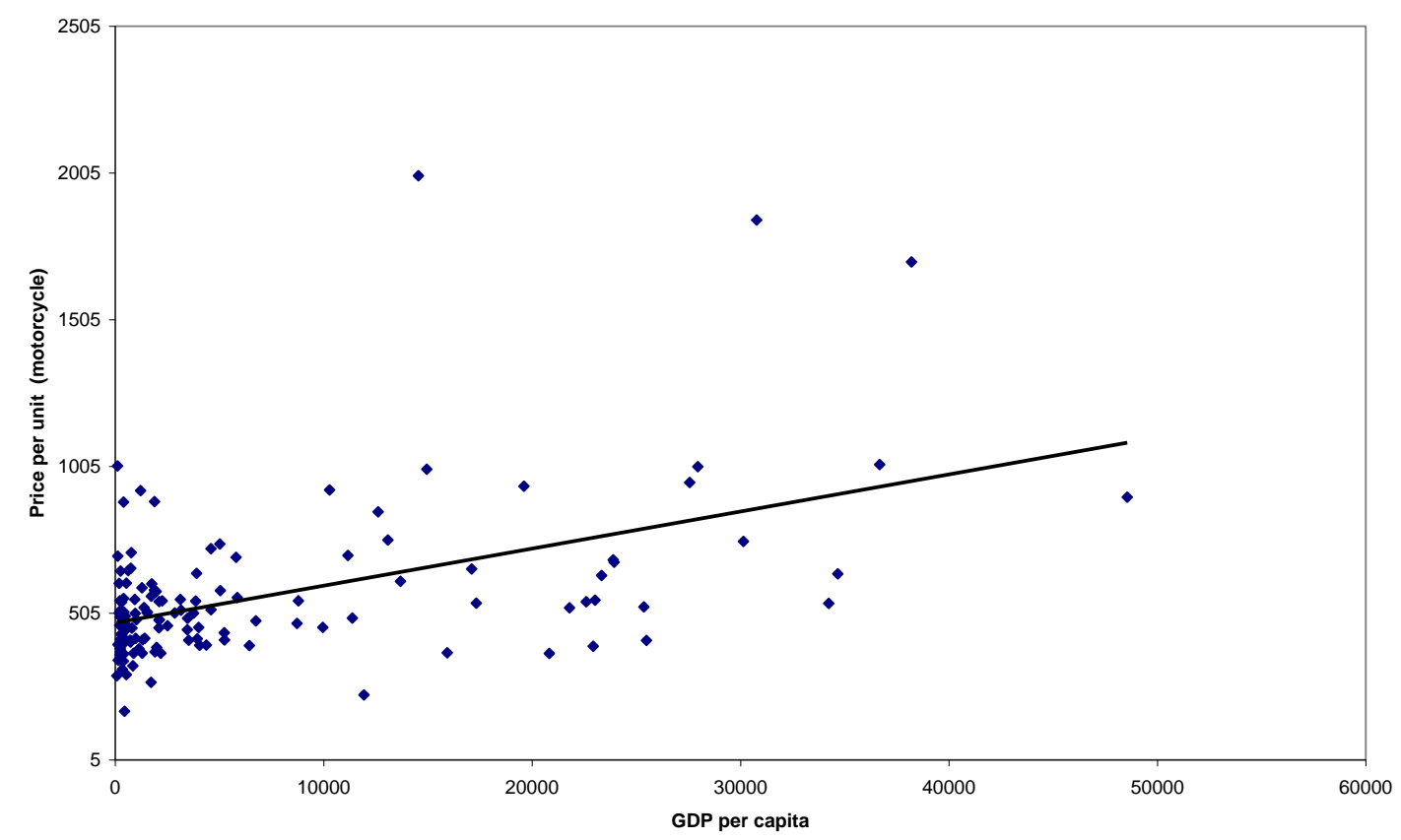


Table 1: Description of HS 2-digit Industries and Number of Observations

\begin{tabular}{|c|c|c|}
\hline HS Code & Description & Observations \\
\hline $1-5$ & $\begin{array}{l}\text { Live animals and animal } \\
\text { products }\end{array}$ & 3,893 \\
\hline $6-14$ & Vegetable products & 12,248 \\
\hline 15 & Fats oils and waxes & 608 \\
\hline $16-24$ & $\begin{array}{l}\text { Food products, } \\
\text { beverages \& tobacco }\end{array}$ & 9,192 \\
\hline $25-27$ & Mineral products & 5,320 \\
\hline $28-38$ & Chemicals & 54,641 \\
\hline $39-40$ & Plastics and rubber & 18,464 \\
\hline $41-43$ & Leather, fur etc. & 5,625 \\
\hline $44-46$ & $\begin{array}{l}\text { Wood and Wood } \\
\text { products }\end{array}$ & 6,177 \\
\hline $47-49$ & $\begin{array}{l}\text { Wood pulp, paper and } \\
\text { paper articles }\end{array}$ & 9,131 \\
\hline $50-63$ & Textiles & 83,214 \\
\hline $64-67$ & Footwear, headwear etc. & 8,791 \\
\hline $68-70$ & $\begin{array}{l}\text { Glass, glassware, stone } \\
\text { and ceramics }\end{array}$ & 16,713 \\
\hline 71 & $\begin{array}{l}\text { Pearls, precious metals } \\
\text { and jewellery }\end{array}$ & 1,417 \\
\hline $72-83$ & Base metals & 49,766 \\
\hline $84-85$ & $\begin{array}{l}\text { Machinery, mechanical, } \\
\text { electrical equipment }\end{array}$ & 91,336 \\
\hline $86-89$ & $\begin{array}{l}\text { Vehicles, aircraft and } \\
\text { transportation } \\
\text { equipment }\end{array}$ & 11,505 \\
\hline $90-92$ & $\begin{array}{l}\text { Clocks, watches and } \\
\text { specialist instruments }\end{array}$ & 22,140 \\
\hline $94-96$ & $\begin{array}{l}\text { Other manufactured } \\
\text { goods }\end{array}$ & 25,773 \\
\hline
\end{tabular}


Table 2: The Relationship between Unit Value, Distance and Market Size by sector

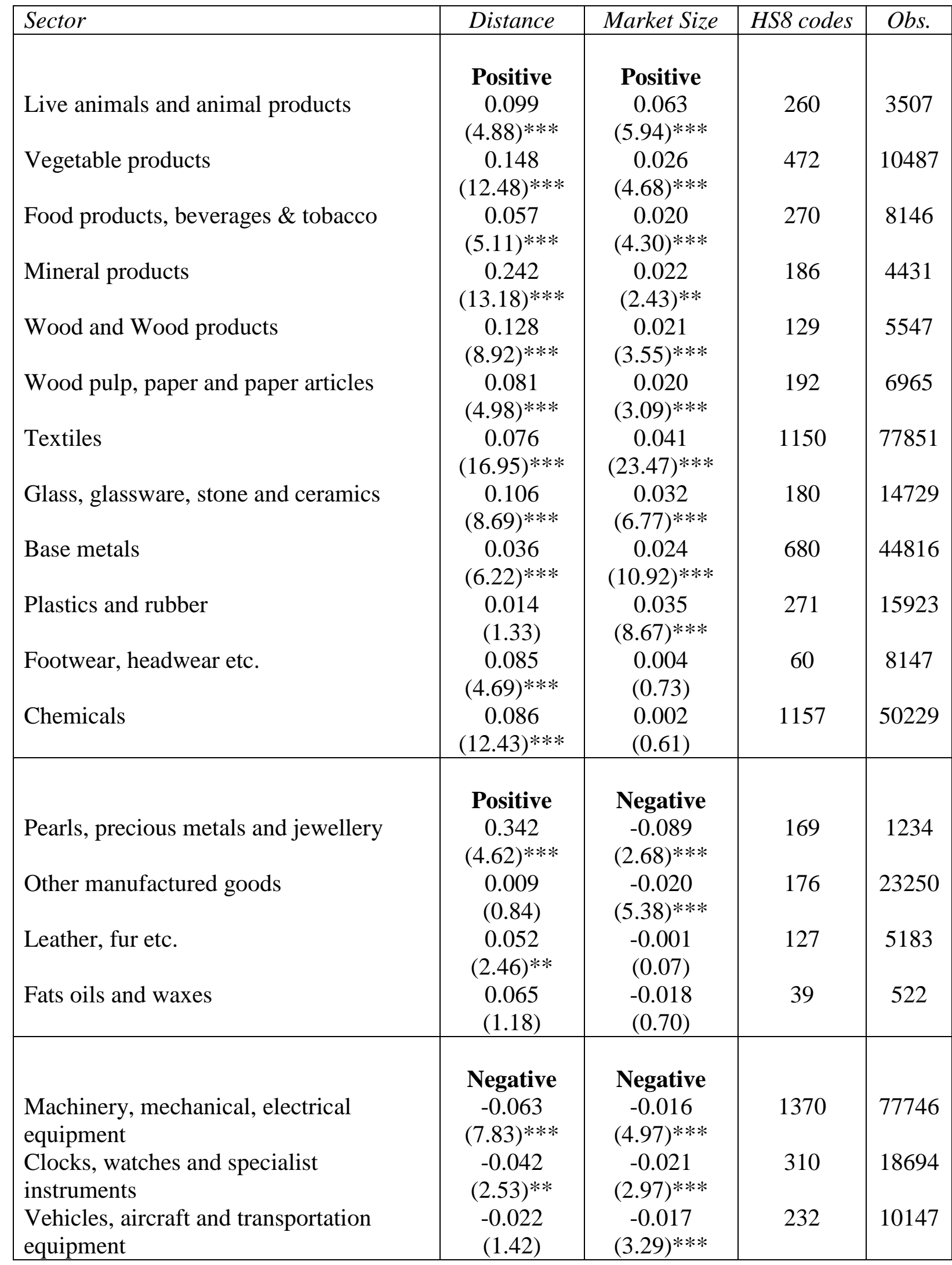

Notes: Notes

+ significant at $10 \% ; *$ significant at $5 \% ; * *$ significant at $1 \%$

OLS regressions at country-product-year level, regressing unit value on country characteristics with HS8 product fixed effects. They additionally includes measures of common borders, GDP per capita and separate time dummies for the years 1997, 2000 and 2002. The coefficients on distance and market size are reported. 
Table 3: Predictions from Heterogeneous Firm Trade Model with Quality Differences and Spatial Price Discrimination

\begin{tabular}{|c|c|c|c|}
\hline \multicolumn{4}{|c|}{ Quality Sorting (>1) Model } \\
\hline Relationship with & Selection Effect & $\begin{array}{c}\text { Price } \\
\text { discrimination } \\
\text { Effect }\end{array}$ & Total Effect \\
\hline Distance & + & - & $+1-$ \\
\hline Market Size & + & - & $+/-$ \\
\hline \multicolumn{4}{|c|}{ Efficiency Sorting $(<1)$ model } \\
\hline Relationship with & Selection Effect & $\begin{array}{c}\text { Price } \\
\text { discrimination } \\
\text { Effect }\end{array}$ & Total Effect \\
\hline Distance & - & - & - \\
\hline Market Size & - & - & - \\
\hline
\end{tabular}


Table 4. Summary of Empirical Findings and Their Theoretical Interpretation

\begin{tabular}{|c|c|c|c|}
\hline $\begin{array}{c}\text { Sign on } \\
\text { Distance, Market size }\end{array}$ & $\begin{array}{c}\text { Sorting pattern } \\
\text { implied }\end{array}$ & Comment & $\begin{array}{l}\text { Empirical } \\
\text { Evidence for } \\
\text { China }\end{array}$ \\
\hline,++ & Quality sorting & $\begin{array}{l}\text { Selection effects } \\
\text { dominates }\end{array}$ & $\begin{array}{l}\text { Majority of } \\
\text { Chinese } \\
\text { industries }\end{array}$ \\
\hline,+- & Quality sorting & $\begin{array}{l}\text { Selection (price } \\
\text { discrimination) } \\
\text { effect dominates } \\
\text { for distance } \\
\text { (market size), }\end{array}$ & $\begin{array}{c}\text { Four Chinese } \\
\text { industry } \\
\text { (plus US } \\
\text { exports) }\end{array}$ \\
\hline,-- & $\begin{array}{l}\text { Efficiency sorting } \\
\text { or quality sorting }\end{array}$ & $\begin{array}{c}\text { Price } \\
\text { discrimination } \\
\text { effect dominates }\end{array}$ & $\begin{array}{c}\text { Two Chinese } \\
\text { industries }\end{array}$ \\
\hline,-+ & Quality sorting & $\begin{array}{c}\text { Price } \\
\text { discrimination } \\
\text { (Selection) effect } \\
\text { dominates for } \\
\text { distance (market } \\
\text { size) }\end{array}$ & No evidence \\
\hline
\end{tabular}




\section{References}

Antoniades, Alexis (2015), Heterogeneous Firms, Quality and Trade, Journal of International Economics, 95(2), 263-273

Baldwin, Richard and James Harrigan (2011), "Zeroes, Quality and Space: Trade Theory and Trade Evidence", American Economic Journal: Microeconomics, 3(2): 60-88

Baller, Silja (2013), "Product Quality, Market Size and Welfare: Theory and Evidence from French Exporters", Job Market Paper, Department of Economics, University of Oxford

Bastos, P. and J. Silva (2010) "The quality of a firm's exports: Where you export to matters", Journal of International Economics, 82(2), 99 -111.

Bernard, Andrew , Bradford Jensen, Steve Redding , and Peter Schott (2007) , 'Firms in International Trade' , Journal of Economic Perspectives, American Economic Association, 21(3), 105130, Summer.

Choi, Yo Chul, David Hummels and Chong Xiang (2006), 'Explaining Import Variety and Quality: The Role of the Income Distribution,' NBER Working Papers 12531, National Bureau of Economic Research

Di Comite, Francesco, Jacques-Francois Thisse and Hylke Vandenbussche (2014), "Vertizontal Differentiation in Monopolistic Competition", Journal of International Economics, 93(1) 50-66

Eaton Jonathan and Samuel Kortum (2002), "Technology, Geography and Trade” , Econometrica , 70(5), 1741-1779

Eckel, Carsten, Leonardo Iacovone, Beata S. Javorcik and J. Peter Neary (2015), "Multi-Product Firms at Home and Away: Cost- vs Quality-based Competence", Journal of International Economics, 95(2), 216-232

Görg, H., L. Halpern, and B. Murakozy (2010), "Why Do within Firm-Product Export Prices Differ Across Markets?”, CEPR Working Paper 7708

Johnson, Robert (2012), “Trade and Prices with Heterogeneous Firms," Journal of International Economics, 86(1) , 43-56

Hallak, Juan Carlos (2006), 'Product Quality and the Direction of Trade', Journal of International Economics, 68(1), 238-265

Hallak, Juan Carlos and Peter K. Schott (2008), 'Estimating Cross-Country Differences in Product Quality,' NBER Working Papers 13807

Harrigan, James and Deng, Haiyan (2008), “China’s Local Comparative Advantage”, NBER Working paper 13963

Head , Keith and Thierry Mayer (2002), 'Illusory Border Effects: Distance Mismeasurement Inflates Estimates of Home Bias in Trade,' Working Papers 2002-01, CEPII research center.

Hummels,David and Peter J. Klenow (2005), 'The Variety and Quality of a Nation's Exports', American Economic Review 95(3) , 704-724 
Hummels, David and Skiba, Alexandre (2004), 'Shipping the Good Apples Out? An Empirical Confirmation of the Alchian-Allen Conjecture,' Journal of Political Economy, 112(6), 1384-1402, December.

Manova, Kalina and Zhiwei Zhang (2012), "Export Prices Across Firms and Destinations", The Quarterly Journal of Economics, 127 (1), 379-436

Martin, Julien (2012), “Markups, Quality and Transport Costs”, European Economic Review, 56(4), $777-791$

Melitz, Marc (2003), 'The Impact of Trade on Intra-Industry Reallocations and Aggregate Industry Productivity.' Econometrica 71(6), pp. 1695-1725

Melitz, Marc , Gianmarco Ottaviano (2007), 'Market Size, Trade, and Productivity', Review of Economic Studies 75(1), 295 - 316

Schott, Peter, 2004, ' Across-Product versus Within-Product Specialization in International Trade', Quarterly Journal of Economics 119, 647-678.

Schott, Peter, 2008. 'The relative sophistication of Chinese exports,' Economic Policy, 53(January), $5-49$ 


\section{Appendix}

Table A1 : Number of HS8 Products Exported to Each Country from China

\begin{tabular}{|c|c|c|c|c|c|c|c|}
\hline country & $\begin{array}{l}\text { No of } \\
\text { HS8 } \\
\text { product } \\
\text { s }\end{array}$ & country & $\begin{array}{l}\text { No of } \\
\text { HS8 } \\
\text { product } \\
\text { s }\end{array}$ & country & $\begin{array}{l}\text { No of } \\
\text { HS8 } \\
\text { product } \\
\text { s }\end{array}$ & country & $\begin{array}{l}\text { No of } \\
\text { HS8 } \\
\text { produ } \\
\text { cts }\end{array}$ \\
\hline Algeria & 2,997 & $\begin{array}{l}\text { El } \\
\text { Salvador }\end{array}$ & 1,722 & Laos & 744 & $\begin{array}{l}\text { Saudi } \\
\text { Arabia }\end{array}$ & 6,170 \\
\hline Angola & 1,263 & Ethiopia & 2,441 & Liberia & 453 & Senegal & 1,122 \\
\hline Argentina & 4,712 & Fiji & 1,769 & $\begin{array}{l}\text { Madagasca } \\
\mathrm{r}\end{array}$ & 2,162 & Seychelles & 499 \\
\hline Australia & 9,849 & Finland & 4,281 & Malawi & 416 & $\begin{array}{l}\text { Sierra } \\
\text { Leone }\end{array}$ & 574 \\
\hline Austria & 3,366 & France & 7,813 & Malaysia & 10,325 & Singapore & $\begin{array}{l}11,09 \\
6\end{array}$ \\
\hline Bahamas & 227 & Gabon & 506 & Mali & 494 & $\begin{array}{l}\text { Solomon } \\
\text { Islands }\end{array}$ & 443 \\
\hline Bahrain & 1,883 & Gambia & 774 & Malta & 1,898 & $\begin{array}{l}\text { South } \\
\text { Africa }\end{array}$ & 7,176 \\
\hline Bangladesh & 5,772 & Germany & 10,050 & Mauritania & 583 & Spain & 7,546 \\
\hline Belize & 514 & Ghana & 2,810 & Mauritius & 3,222 & Sri Lanka & 4,952 \\
\hline Benin & 1,860 & Greece & 5,438 & Mexico & 5,253 & $\begin{array}{l}\text { St Kitts and } \\
\text { Nevis }\end{array}$ & 29 \\
\hline Brazil & 5,774 & $\begin{array}{l}\text { Guatema } \\
\text { la }\end{array}$ & 2,624 & Mongolia & 2,808 & Sudan & 2,614 \\
\hline Bulgaria & 2,331 & Guinea & 1,054 & Morocco & 3,820 & Suriname & 1,520 \\
\hline Burkina Faso & 258 & $\begin{array}{l}\text { Guinea } \\
\text { Bissau }\end{array}$ & 93 & $\begin{array}{l}\text { Mozambiq } \\
\text { ue }\end{array}$ & 1,052 & Sweden & 4,778 \\
\hline Burundi & 203 & Guyana & 1,076 & Nepal & 1,560 & Switzerland & 4,171 \\
\hline Cameroon & 1,521 & Haiti & 565 & $\begin{array}{l}\text { New } \\
\text { Zealand }\end{array}$ & 6,016 & $\begin{array}{l}\text { Syrian } \\
\text { Arab } \\
\text { Republic }\end{array}$ & 3,525 \\
\hline Canada & 8,603 & $\begin{array}{l}\text { Hondura } \\
\mathrm{s}\end{array}$ & 1,700 & Nicaragua & 896 & Tanzania & 2,258 \\
\hline $\begin{array}{l}\text { Central } \\
\text { African } \\
\text { Republic }\end{array}$ & 94 & $\begin{array}{l}\text { Hong } \\
\text { Kong }\end{array}$ & 14,984 & Niger & 189 & Thailand & 9,262 \\
\hline Chad & 50 & Hungary & 3,709 & Nigeria & 4,743 & Togo & 1,093 \\
\hline Chile & 5,757 & Iceland & 566 & Norway & 3,616 & $\begin{array}{l}\text { Trinidad } \\
\text { And } \\
\text { Tobago }\end{array}$ & 1,665 \\
\hline Colombia & 3,213 & India & 7,161 & Oman & 1,298 & Tunisia & 2,661 \\
\hline Comoros & 49 & $\begin{array}{l}\text { Indonesi } \\
\text { a }\end{array}$ & 9,464 & Pakistan & 6,668 & Turkey & 5,579 \\
\hline Congo & 994 & Iran & 4,594 & Panama & 4,228 & USA & $\begin{array}{l}13,31 \\
3\end{array}$ \\
\hline Costa Rica & 2,081 & Iraq & 16 & Papua New & 1,897 & Uganda & 895 \\
\hline
\end{tabular}




\begin{tabular}{|ll|ll|ll|ll|}
\hline & & & & Guinea & & \\
Cote D'Ivour & 1,835 & Ireland & 2,572 & Paraguay & 1,720 & UAE & 7,953 \\
Cyprus & 2,914 & Italy & 8,957 & Peru & 3,796 & UK & 9,210 \\
Czechoslovak & 3,398 & Jamaica & 1,480 & Philippines & 8,242 & Uruguay & 3,108 \\
ia & & & & & & & \\
Denmark & 4,501 & Japan & 14,019 & Poland & 4,579 & Venezuela & 3,860 \\
Djibouti & 1,067 & Jordan & 4,491 & Portugal & 3,673 & Yemen & 3,094 \\
Dominican & 2,170 & Kenya & 3,225 & Romania & 3,394 & Zambia & 1,077 \\
Republic & & & & & & & \\
Ecuador & 3,026 & Korea & 12,541 & Rwanda & 276 & Zimbabwe & 1,554 \\
Egypt & 6,056 & Kuwait & 3,620 & & & & \\
\hline
\end{tabular}

